<総 説 $>$

(受理 : 平成 22 年 4 月 2 日)

\title{
木材とプラスチックの複合化について Composite of Wood and Plastic
}

\section{1. はじめに}

木材とプラスチックを複合化した素材をウッドプラスチッ クと呼ぶが，このウッドプラスチックは，熱硬化性樹脂と 複合した含浸型ウッドプラスチックと熱可塑性樹脂と複合 した混練型ウッドプラスチックに大別される。本総説では, 近年デッキ材等のエクステリア用途を中心に拡大している 混練型ウッドプラスチックについて述べる。混練型ウッド プラスチック（以降ウッドプラスチックと呼ぶ）は，力テ ゴリーとして，タルクや炭酸カルシウム等の無機フィラー を充填したフィラー充填プラスチックに分類されるが，一 般的な無機フィラーに比べてフィラー充填率を高くできる ことが特徴の一つとなっている。実際, 欧州中心に木粉充 填率 $80 \%$ 以上のマット成型製品実績が，自動車用途に用 いられている。しかしながら，汎用的なウッドプラスチッ ク用途では，充填率 $50 \%$ 程度が中心である。一方，木粉 は元来㵶維系材料であるが，ウッドプラスチック用途にお いて，この繊維特性はほとんど活かされていない。そこで, 本総説では，冒頭でウッドプラスチックの概要を解説する が，主題は，ウッドプラスチックのさらなる可能性を秘め た特性である高充填, 織維特性を利用した新たなウッドプ ラスチックについて述べる。

\section{2. ウッドプラスチックの概要}

\section{1 ウッドプラスチックの種類}

ウッドプラスチックは，木粉の充填率で大きく 3 タイブ

*ヤマハリビングテック(怢) 事業企画推進部 静岡県浜松市西区西山町 1370 番地 テ 432-8001

Yamaha Livingtec Co. Ltd

1370, Nishiyama-cho, Nishi-ku, Hamamatsu, Shizuoka 432-8001, Japan

** 近畿大学

奈良県奈良市中町 3327-204 干 631-8505

Kinki Univ.

3327-204, Naka-machi, Nara 631-8505, Japan
伊藤 弘和 $*$ ・高谷 政広 ${ }^{* *}$ Hirokazu ITO and Masahiro TAKATANI

\begin{tabular}{|c|c|c|c|}
\hline \multirow{2}{*}{$\begin{array}{l}\text { 木粉 } \\
\text { 充填率 }\end{array}$} & $25 \%$ & $50 \%$ & $100 \%$ \\
\hline & 低充填 & 中充填 & 高充填 \\
\hline ポイント & 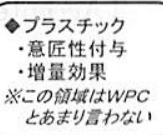 & $\begin{array}{l}\Delta \text { 中間 } \\
<\text { 対木材> } \\
\text { 和久性向上 } \\
<\text { 対ブラスチック } \\
\text { ·機械特性向上 }\end{array}$ & $\begin{array}{l}\text { 《材 } \\
\text { ·形状が自由 } \\
\text { ·寸法安定 } \\
\text { ·マテリアルリサ } \\
\text { クル }\end{array}$ \\
\hline
\end{tabular}

図 1 混練型ウッドプラスチックの分類

に分類される（図 1)。充填率が 10\%前後のウッドプラス チックは，プラスチック製品に木質意匠感を付与するため に木粉を添加しており，主に建築材料を中心に木目調のプ ラスチック製品として広く利用されている。充填率が $50 \%$ 前後のウッドプラスチックは，木質感の意匠付与効果もあ るが，耐水性等の耐久性能が必要なエクステリアに代表さ れる屋外の用途に利用されており，ウッドプラスチックに

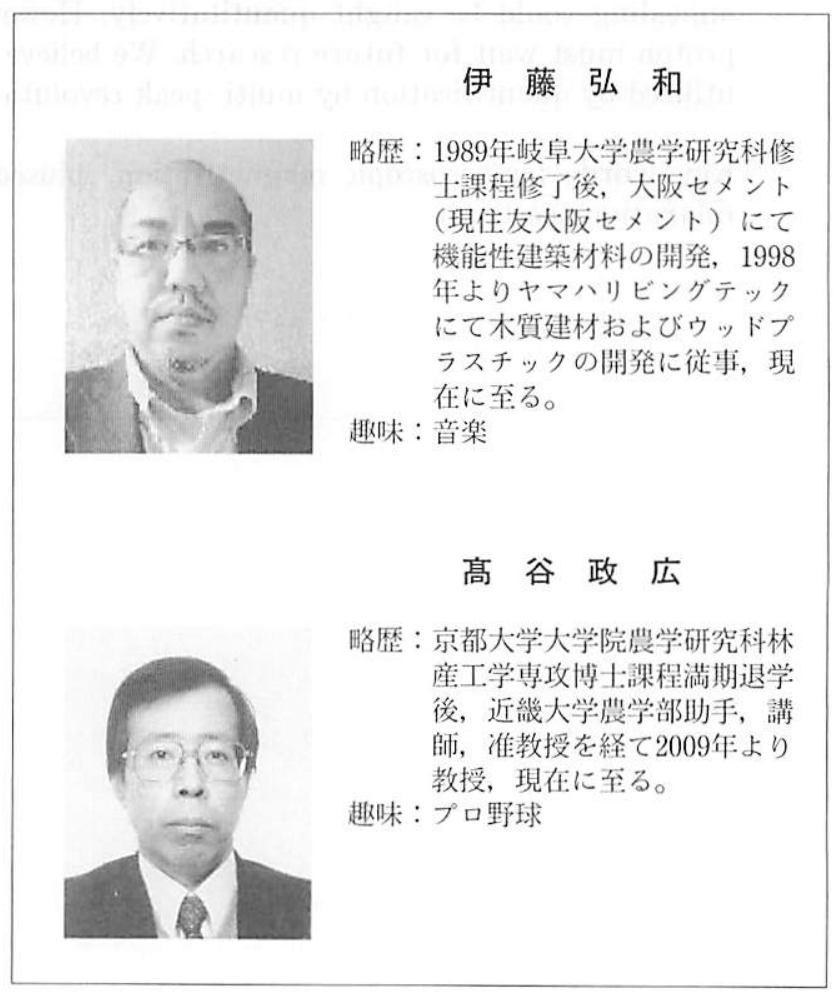


おいては，最も汎用なタイプである。また，充填率が $70 \%$ を超えるウッドプラスチックは, 自由な形状に成形できる 効果を活かし，木材の代替として，注目を集めており，国 内においても学術機関を中心に研究レベルでは進んでいる むのの，まだ拡大的な実用化には至っていない1。

\section{2 ウッドプラスチックの製法}

冒頭にも述べたが, ウッドプラスチックはフィラー充填 プラスチックのカテゴリーであるため，その製法もほとん ど同じである。図 2 には, 製法のフロー図を示す。木粉, プラスチック，混和剂等の原材料を所定の配合でプラスチッ クの溶融する温度で混合したものをコンパウンド（この工 程をコンパウンド化）と言い，一般的にはハンドリング性 からペレット形状に加工し，このコンパウンド化したペレッ トを押出成形や射出成型をして製品を得る。ここで, 原料 である木粉は一般的な無機フィラーに比べて吸水や吸湿し やすい素材であるため, 乾燥工程が不可欠となる。乾燥が 不十分な木粉を用いると, 成形不良や凝集が生じ, 製品性 能に影響を及ぼすため，留意すべきである。

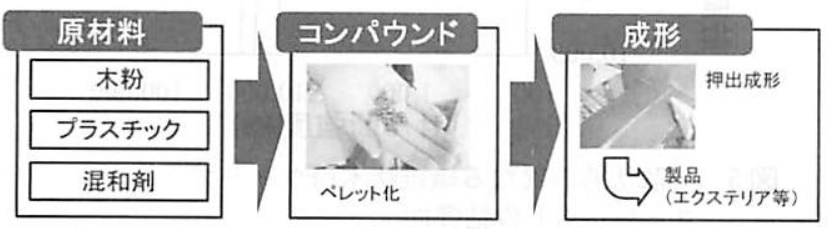

図 2 混練型ウッドプラスチックの製法フロー図

\section{3 ウッドプラスチックの原料}

原材料として用いる木粉は，一般的に $100 \sim 300 \mu \mathrm{m}$ 程 度に粉砕して利用される。前述したが, 含水率は重要な因 子で，5\%以下が望ましいとされている。また，国内にお いてウッドプラスチックに利用されている樹種は，スギ， ベイッガ，ヒノキ等が中心である。この理由は樹種の適性 よりはむしろ, 調達の容易さが事由となっている。

木粉は, $230^{\circ} \mathrm{C}$ 超えると著しく变質するため, 利用で きるプラスチックは融点が $200^{\circ} \mathrm{C}$ 以下のオレフィン系プラ スチック（ポリエチレン，ポリプロピレン等）、スチレン 系プラスチック（ポリスチレン $\mathrm{ABS}$ 等）が一般的で，用 途や目標とする性能に合わせて使用されている。しかしな がら，短時間であれば变質も少ないので，融点が $230^{\circ} \mathrm{C}$ を 超えるプラスチックとの複合化事例屯ある2)。木粉が天然 素材である観点から, 植物由来のプラスチックとの複合化 事例む多く3 5)，期待できる素材であるが，エクステリア 用途等建築材料中心の国内用途では，コスト的な課題があ る。

木粉は親水性の素材であり, ウッドプラスチックに用い るプラスチックは疎水性であり，この両者は相溶性がない。 通常のフィラー充填プラスチックにおいて相溶性のない素

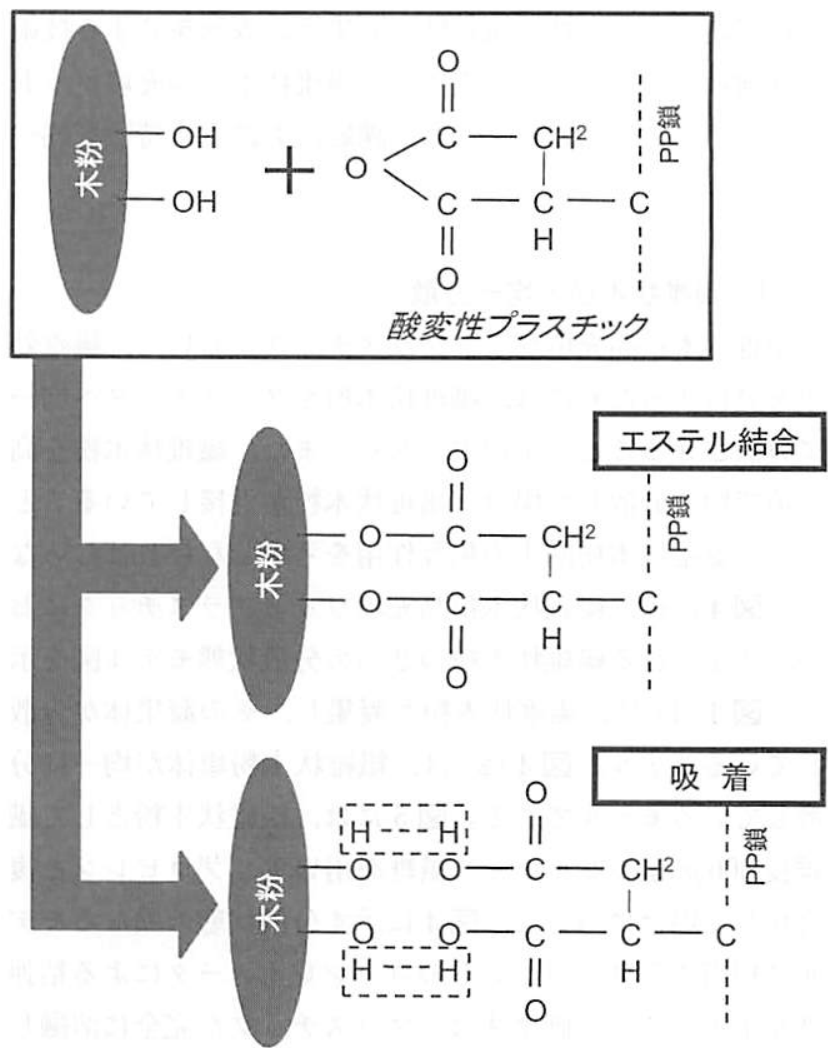

図 3 酸変性プラスチックによる木粉の改質

材の複合体は，機械的特性，而久特性等の様々な特性にお いて効果を発現しないことが周知であり，ウッドプラスチッ クあ同じである。一般的な無機フィラーを用いたフィラー 充填プラスチックの場合, 無機フィラーにカップリング処 理（疎水処理）を実施する。このカップリング処理は，ウッ ドプラスチックにおける木粉の処理にあ有効な手法である が 6 9), 木粉は無機フィラーに比べて見かけ密度が低くか さ高い点や親水基が無機素材に比べ密接してカップリング 効率が低い点から, 量産性が困難で, ウッドプラスチック では, 酸变性プラスチックを相溶化剂として利用している ことが多い。酸変性プラスチックは, ベースプラスチック の一部をマレイン酸等で变性し親水性と踈水性の両極性を 付与している。図 3 に示すように，木粉表面上の親水部分 ( $\mathrm{OH}$ 基) に, 酸変性部分（図では無水マレイン酸）がエ ステル結合 ${ }^{10)}$ あるいは吸着 ${ }^{11)}$ し，木粉表面とプラスチック の相溶性を高くすることで改質する相溶化㓮である $\left.{ }^{12} 17\right) 。$

\section{3. 繊維状木粉を用いた高充填ウッドプラスチック}

緎維状の木粉（厳密には植物性粉末とすべきであるが以 下木粉と呼ぶ）として天然素材では大麻，麻，ケナフ等, 加工品ではパルプ等が挙げられ，これら素材でウッドプラ スチック化すれば織維補強効果が期待できる。さらにウッ ドプラスチックは高充填化が可能であり, 䄉維状素材が高 充填のプラスチック製品として, 従来にない新素材が提案 できる。しかしながら，この実現には，織維状木粉のコス 
卜の問題や, 生産性, 流動性, 凝集等, 改善を要する技術 的課題は多い。そこでここでは, 䌦維状木粉高充填ウッド プラスチックに関して,これら課題点も踏まえ特徵を述べ る。

\section{1 繊維状木粉の均一分散}

繊維状木粉高充填ウッドプラスチックにおいて, 繊維効 果を発現するためには, 䄉維状木粉をプラスチックへ均一 に分散させることが不可欠となる。また，䋐維状木粉を高 充填で均一分散した場合, 䋐維状木粉が近接していること から, 織維状木粉同士の相互作用を考慮しなければならな い。図 4 には, 織維状木粉高充填ウッドプラスチックにお いて想定される織維状木粉の 2 つの分散状態モデル図を示 す。図 4 (1) は, 䄉維状木粉が疑集し, その凝集体が分散 しているモデル, 図 4 (2) は, 絨維状木粉単体が均一に分 散しているモデルである。図 5 には, 䋊維状木粉として織 維長 $300 \mu \mathrm{m}$ のセルロース䋐維を用いポリプロピレンと複 合化した場合について, 図 4 に示す分散状態の異なるモデ ルに相当するコンパウンドのコーンレオメータによる粘弾 性を示す。この評価手法は, プラスチックが完全に溶融し ている温度 $\left(210^{\circ} \mathrm{C}\right)$ で測定しているので, 織維状木粉相 互間の相互作用が確認できる。䄉維状木粉の充填量が増す 之, 相互作用は強くなると予想され, 䋐維状木粉が均一分 散しているコンパウンド（モデル図；図４（2））では，眝 蔵弾性率, スリップに至る強度とも充填量の増加に伴い高 くなっている(図 5 (2))。しかしながら, 凝集が認められ るコンパウンド（モデル図；図 4 (1)) では, 充填量即ち 繊維間相互作用之弾性率の相関関係は認められない（図 5 (1))。この相互作用には, 繊維の絡み合いのような綫維間 相互作用が含まれ，実際に綫維長の短い䄉維状木粉を用い た場合はこの相互作用の寄与は小さい ${ }^{18)} 。 こ の$ 絡み合い による相互作用は, 䄉維状木粉高充填ウッドプラスチック に特異に発現する現象であり，次項で絡み合いが及ぼす効 果を解説する。

\section{2 絡み合いによる相互作用の効果}

コンパウンドの粘弾性評洒結果で絡み合いによる相互作 用により弾性率等が増加していることから,このコンパウ ンドを用いた成形体においても効果は持続すると期待でき る。図 6 には, 前述の䄉維状木粉が均一分散しているコン パウンド（モデル図；図４（2））を用いプレス成形した成 形体の常態及び吸水曲げ強度を示す。常態の曲げ強度は, 䄉維状木粉の充填量が增加して屯ほとんど差がないのに対 し, 吸水曲げ強度では, 充填率が増加するほど吸水による 強度低下は顕著になる。ウッドプラスチックにおいて強度 を保持している因子はプラスチック成分であり，䄉維状木 粉の充填量が增加するとプラスチックに依存する強度因子

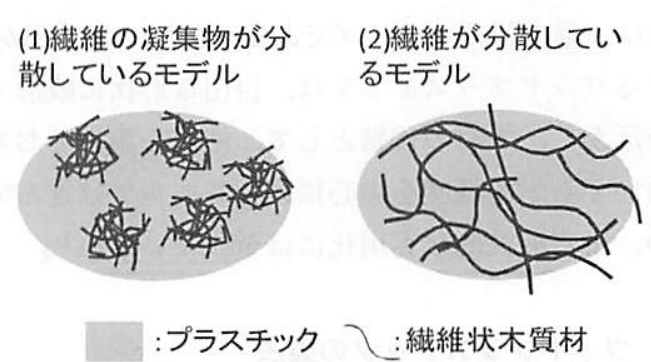

図 4 瀻維状木粉高充填ウッドプラスチックにおける 䋐維状木粉の分散モデル
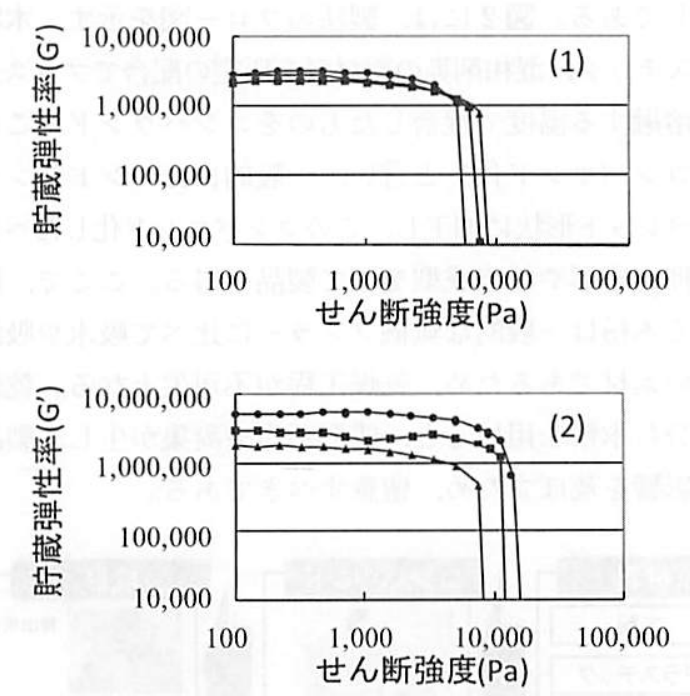

図 5 分散状態の異なる瀻維状木粉ウッドプラスチック コンパウンドの粘弾性
(1) 繊維状木粉が疑集しているコンパウンド,
(2) 織維状木粉が均一に分散しているコンパウンド
○; 織維状木粉充填量 $90 \%$,
口; 䄉維状木粉充填量 $80 \%$,
山; 織維状木粉充填量 $70 \%$

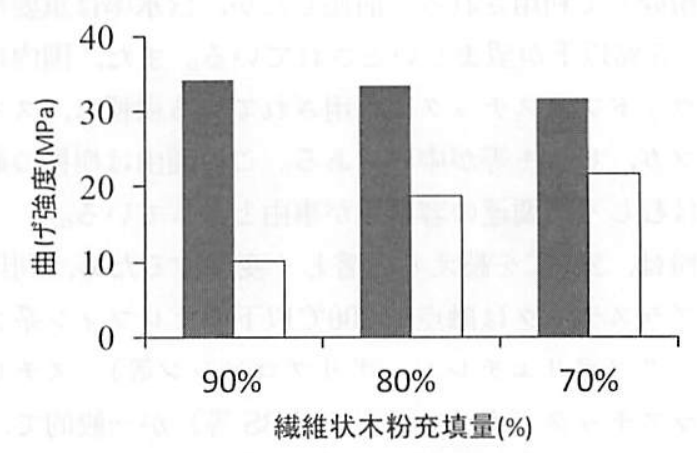

図 6 相互作用のある綫維状木粉高充填ウッド プラスチックの曲げ強度

口; 常態曲げ強度， $\square$; 吸水曲げ强度

が滅少する。また，前述する粘弾性の結果からも明らかな ように, 䄉維状木粉充填量が高くなると絡み合いによる織 維同士の相互作用という新たな強度因子が発現する。した がって, 常態の曲げ強度は, 緎維状木粉が増加とともに, プラスチック成分から相互作用に強度因子がシフトする。 一方, 吸水常態での曲げ強度は, 相互作用による強度因子 が高くなるほど, 強度低下が大きくなっている, 即ち, 相 


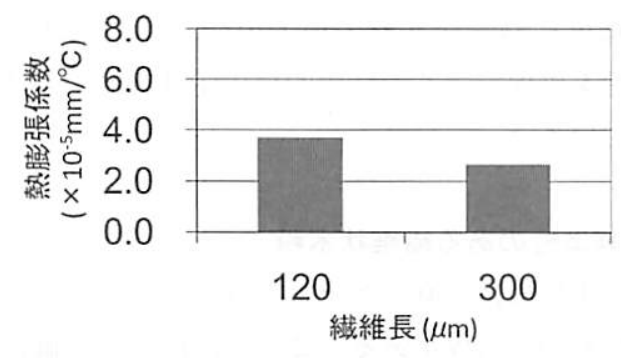

図 7 織維状木粉高充填ウッドプラスチックの熱膨張

互作用は, 吸水により破壊されている。吸水により破壊さ れる結果から，この絡み合いによる相互作用を保持してい る因子は水素結合であることが示唆される ${ }^{19}$ 。言い換えれ ば, 絡み合いによる相互作用は, 補強効果はあるあのの耐 水を必要とする用途展開には課題があると言える。

一方, 図 7 には, 䄉維状木粉が均一に分散している成形 体において, 絡み合いによる相互作用が発現する瀻維状木 粉（織維長 $300 \mu \mathrm{m}$ ） 之相互作用の寄与が小さい短い緎維 状木粉（綫維長 $120 \mu \mathrm{m}$ ）を用いたプレス成形体の熱膨張 を示す。絡み合いによる相互.作用の発現が熱膨張の低下に 効果的に㗢いている ${ }^{20)}$ 。即ち, 絡み合いは熱に安定であり, ウッドプラスチックの熱膨張抑制に利用できる技術である。

\section{3 瀻維状木粉高充填ウッドプラスチックの流動性}

織維状木粉高充填ウッドプラスチックを成形するにあた り，流動性は大きなポイントとなる。ウッドプラスチック において，これはフィラー充填プラスチック一般に共通す るが，プラスチック成分は流動に寄与しており，プラスチッ ク成分の少ない繊維状木粉高充填ウッドプラスチックで流 動性が低いことは明らかである。図 8 には, 織維状木粉を 用いてコンパウンド化した場合のスクリュー1回転あたり の単位吐出量を示す。繊維状木粉充填量が高くなるほど単 位吐出量即ち生産性が低くなっている。これは, プラスチッ ク成分が少なくなることによる流動性の低下むあるが，織 維状木粉は織維間に空隙を多く巻き込み見掛け密度が小さ くなっていることが要因となっている。コンパウンドの生 産性においてこの点は大きな課題となるが,一旦コンパウ ンド化すれば減溶化されるため, 䄉維状木粉の見掛け密度 は無視できる。図 9 には, 織維状木粉高充填ウッドプラス チックコンパウンドの MFR (Melt Flow Rate)を示す。 MFR はプラスチックの流動性を測定する汎用な試験方法 (JIS K 7210) であるが, 䄉維状木粉高充填ウッドプラス チックは流動性が低いため,ここでは試験条件を変更して 測定している (ダイス径 $6 \mathrm{~mm}$, 荷重 $100 \mathrm{~N}$ )。織維状木粉 充填量が高くなると流動性は低くなっており, 表 1 に示す 成形圧力も高くなり，生産性が低くなっている結果と一致 する。しかしながら，前述した絨維間相互作用を有するコ ンパウンドにおいては, チキントロピー性が発現し，流動 性が変化する場合がある21)。図 10 には, 相互作用が発現

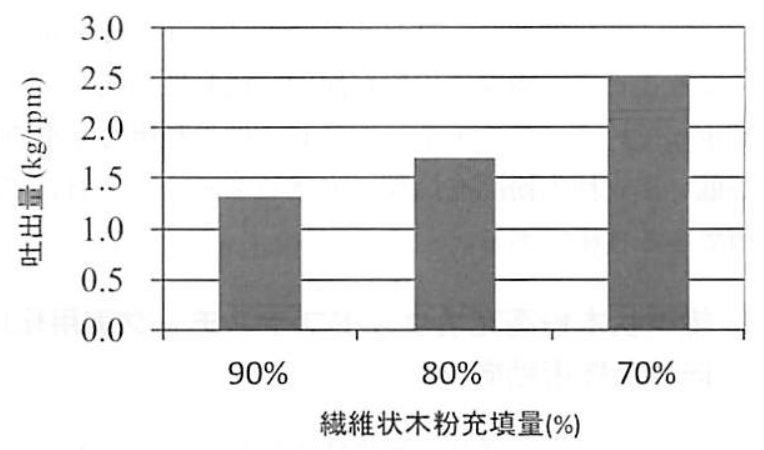

図 8 繊維状木粉高充填ウッドプラスチックコンパウンド の生産性

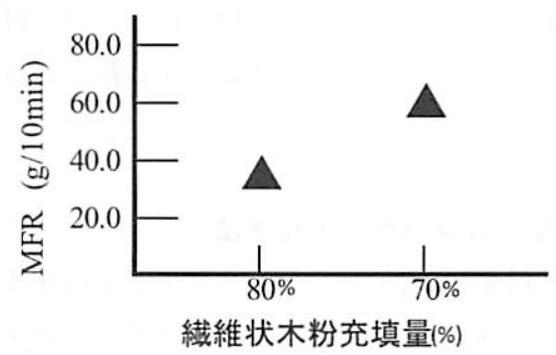

図 9 織維状木粉高充填ウッドプラスチックコンパウンド の MFR

表 1 繊維状木粉充填量と成形圧力

\begin{tabular}{ccc}
\hline $\begin{array}{c}\text { 䄉維状木粉 } \\
\text { 充填量 } \\
(\%)\end{array}$ & $\begin{array}{c}\text { 押出成形压 } \\
(\mathrm{MPa})\end{array}$ & $\begin{array}{c}\text { 射出成型圧 } \\
(\mathrm{MPa})\end{array}$ \\
\hline 70 & 4.8 & 21.5 \\
\hline 80 & 6.1 & 28.8 \\
\hline
\end{tabular}

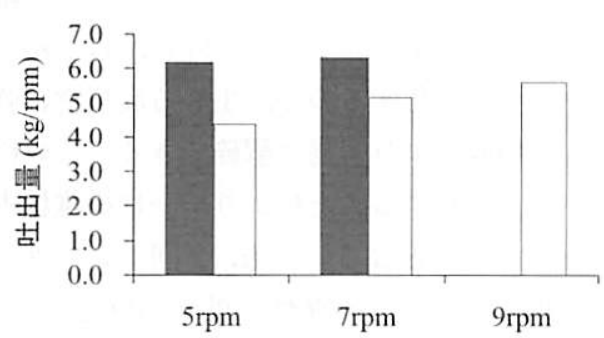

押出成形速度

（スクリュー回転数）

図 10 相互作用の異なる織維状木粉高充填ウッドプラス チックコンパウンドを用いた押出成形の生産性 回相互作用の寄与が小さいコンパウンド(織維状 木粉䄉維長 $120 \mu \mathrm{m}) ， \square$ 相互作用の寄与が大きい コンパウンド（綫維状木粉繊維長 $300 \mu \mathrm{m}$ )

しているコンパウンド（モデル図；図 4 (2)) と発現して いないコンパウンド（モデル図；図 4 (1)）で，押出成形 を実施し，その成形速度を変化させたときの単位叶出量を 比較している。相互作用が発現していないコンパウンド （モデル図；図 4（1））は成形速度が増加しても単位叫出量 に变化がないが, 相互作用が発現しているコンパウンド （モデル図；図 4(2)）では, 単位吐出量が増加する。これ 
は, 成形速度が増加し, コンパウンドにかかるせん断力が 高くなることで, 䄉維状木粉が配向し流動性が変化したこ とを示している。このチキソトロピー性の利用は元来流動 性が低い繊維状木粉高充填ウッドプラスチックにおいて, 活用できる技術である。

\section{4. 繊維状木粉高充填ウッドプラスチック実用化に 向けた技術動向}

前項で述べてきた通り, 綫維状木粉高充填ウッドプラス チックは, 従来のプラスチック素材や木材にはない様々な 特性を有している反面, 実用化するためには, 生産性, 凝 集, 耐水性, コスト等改善しなければならない課題むある。 そこで，以下には，これらの対策となる新しい技術をいく つか紹介する。

\section{1 新たなコンパウンド化手法}

織維状木粉を高充填でプラスチックと複合化する場合, 織維状木粉の凝集は最も詷念されるマイナス因子である。 また，生じた強固な凝集物を再分散することはほとんど不 可能である。このため, コンパウンド工程は最も重要な工 程となる。コンパウンド工程において疑集を防止するため には, 㵶維状木粉を十分乾燥させ，ゆっくりプラスチック とコンパウンド化すれば実現できる。しかしながら, コス 卜面から見ると，これは採用できない手法である。そこで, この凝集を逆手に取った新たなコンパウンド手法が提案さ れている22)。図 11 に, 工程図を示す。この手法のポイン トは, 䌦維状木粉とプラスチックを 2 回コンパウンド化す ることにある。1 回目のコンパウンド化では, 織維状木粉 を乾燥せず，一旦凝集させる。この際に，ほとんど圧力を かけずコンパウンド化するので, 生じる凝集物は強固な凝 集ではなく，粉砕により容易に解碎できる。この粉研物を 再度コンパウンド化することにより均一に綫維状木粉が分 散したコンパウンドとなる。一方, 2 回コンパウンド化す ることで工程が増加し, 生産性の低下が照念されるが, 1 回目のコンパウンド工程は, 高い分散性や混練性を要求さ れずさらに圧力をかけないので, 通常のコンパウンド設備 の 2 倍以上の処理条件で稼働でき, 2 回目のコンパウンド

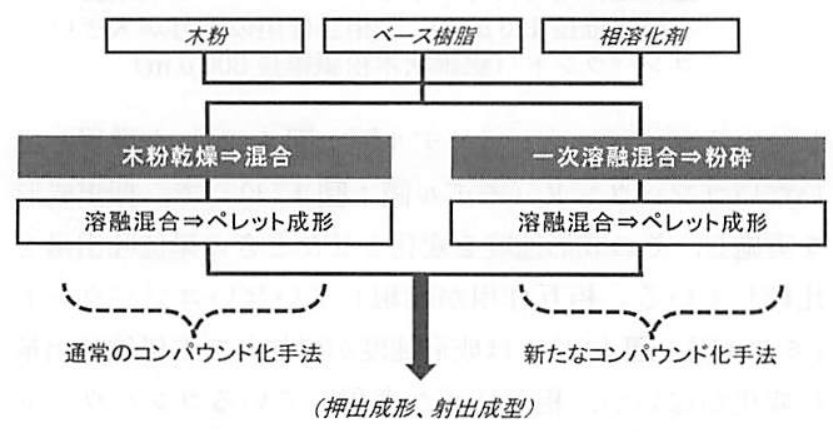

図 11 コンパウンド手法のフロー図比較
は $1 / 3$ 程度に減溶化されているので，通常手法の 3 倍近 い生産性を確保できる。結果的に生産性は従来手法より高 くなっている。

\section{2 経済性のある繊維状木粉}

織維状木粉には大麻，ヶナフ等様々あるが，コスト的な 面で利用範囲に限界がある。ここで，国内で安価に調達で きる織維状木粉として, MDF 粉砕物が挙げられる。MDF は，建築材料に広く利用されているボードであるが，定尺 サイズであるため, 廃材が発生し，この廃材を粉砕すれば 容易に織維状木粉が得られる。しかしながら，MDF は， 接着剤を含有しており，ウッドプラスチック化においてこ の接着剂由来の気化成分が成形性等へ影響を及ぼ, 従来 技術では実用化できない。逆にいえば，気化成分をコンパ ウンド化時点で除去すれば，綫維状木粉として利用できる。 例えば，前述したコンパウンド手法において，2 回コンパ ウンド化により加熱工程で気化成分を除去しウッドプラス チック化した場合, 織維状木粉である MDF 粉末の綫維効 果が発現し, 成形体の曲げ強度は $20 \%$ 以上向上する ${ }^{23)}$ 。 このように MDF 廃材は, 気化成分の問題を改善すれば, 繊維補強効果を有する優れた織維状木粉であり，かつ安侕 に調達できる材料であるため，国内におけるウッドプラス チック用䄉維状木粉の一つとなり得る。さらに, マテリア ル利用方法が少ない MDF 廃材のカスケード型利用法とし て提案できる用途である。

\section{3 流動性の向上}

䄉維状木粉が高充填のウッドプラスチックにおいて，流 動性が低い点は前述した。この改善方法として球状素材を 添加して,この球状効果 (ベアリング効果) により流動性 を改善する手法がある ${ }^{24)}$ 。図 12 には球状素材として $50 \mu \mathrm{m}$ 程度の球状シリカであるフライアッシュを繊維状木粉高充 填ウッドプラスチックに添加した時の MFR（流動性）変 化を示す。フライアッシュ添加量の増加とともに, ベアリ ング効果により流動性が改善されている。さらにここで は詳細を省略するが, 耐水性む改善されている。これは, フライアッシュの添加により成形体が緻密化され，吸水性 が低くなったためである。フライアッシュは, 石炭火力発

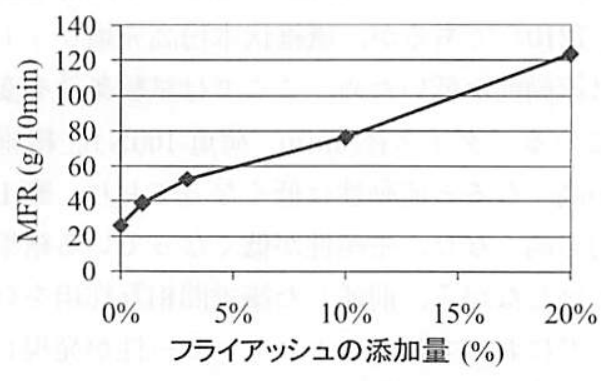

図 12 フライアッシュ添加量と MFR 
電所において石炭を燃燒した際の焼却灰で，比較的安価に 調達できることから，ウッドプラスチックの添加材として は，実用性がある。

\section{5. 環境素材としてのウッドプラスチック}

バイオマス素材は，国内に豊富にある資源であるにあか かわらず，この有効利用が拡大していないのは周知である。 この理由の一つとして, 収集等のコスト面や, アウトプッ トである有効利用法の付加価值用途が少ない点が挙げられ る。この点, ウッドプラスチックは, 付加価值型素材であ る。加えて, 通常 $100 \sim 300 \mu \mathrm{m}$ の木粉として利用するた め, バイオマスのカスケード型利用法として, サーマル利 用に至る前に新たなマテリアル利用の階層を付与すること が可能となる。前述した MDF 廃材利用むこの一例である。 近年, 国内の森林活用として, 自治体を中心に検討されて いる間伐材の有効利用に対しても, ウッドプラスチック用 途は, サーマル利用が中心であるチップサイズ以下のバイ オマスに付加価值型ビジネスを提案でき，採算性のある森 林循環型モデル構築に貢献できる。実際既に, 様々な行政 施策において, ウッドプラスチックは, 具現化事例として 挙げられている。また, ウッドプラスチック素材は, それ 自体プラスチック同様マテリアルリサイクルできる。現状 では, 製造ラインにおいて, 端材等の工程内リサイクルは 実施しているものの，市販に流通しているウッドプラスチッ クを回収してマテリアルリサイクルしている事例はほとん よ゙ない。これは, 汎用のプラスチックに比べ市場流通量が 少ない点や, ライフサイクルが長い用途が中心である等の 事由によるが，環境に対する国民意識の高まりから，近未 来的には, マテリアルリサイクルできる点は, 大きな利点 になる。一方, 木粉を繊維化し, 高充填化することで, 織 維間相互作用と言う従来のフィラー充填プラスチックには ない特性が発現している。この高充填領域におけるプラス チックの役割は, 強度メンバーよりはむしろ成形するため の流動性付与の位置付けが強く, 機能面で利用範囲に制約 のある容器リサイクルプラスチックの活用も可能となる。

\section{5. まとめ}

本総説では，一般的なウッドプラスチックの特性から， ウッドプラスチック素材でしか実現できない織維状素材高 充填化技術を中心に紹介したが，ウッドプラスチックはこ れ以外にも様々な拡張性を有した素材である。しかしなが ら, 新規素材であるが故に，実用化するためにはクリアし なければならない課題点が多いことも事実で, 既存のプラ スチックや木材に比べればその普及率は小さい。ウッドプ
ラスチックの普及拡大に向けた取り組みは，国内外で様々 な研究がなされており, 今回紹介した絰維状木粉高充填ウッ ドプラスチックむその一つである。最後に，接着剂分野に おけるフィラー充填技術は, ウッドプラスチックにおいて 参考にできる研究事例が多く，同様に，ウッドプラスチッ クの研究事例む接着剤分野で活かすことができれば，双方 の技術の相乗的な発展に寄与することが期待できる。

\section{文献}

1）日本木材加工技術協会木材・プラスチック複合材部会編, “ウッドプラスチックのしおり”，日本木材加工技術協会関 西支部， 6 (2005).

2) A. A. Klyosov, "Wood-Plastic Composites", John Wiley \& Sone, 62 (2007).

3) K. Ikeda, M. Takatani, K. Sakamoto, T. Okamoto, Holzforschung, 62, 154 (2008).

4) S. Lee, S. Wang, Y. Teramoto, J. Applied Polymer Sci, 108, 870 (2008).

5) V. P. Cyras, S. Iannace, J. M. Kenny, Polymer Composites, 22, 104 (2001).

6) F. M. B. Coutinho, T. H. S. Costa, D. L. Carvalho, J. Applied Polymer Sci, 65, 1227 (1997).

7) H. Isamil, L. Megal, Polymer Plastics Technology and Engineering, 40, 463 (2001).

8) H. P. S. A. Khalil, H. Ismail, Polymer Testing, 20, 65 (2001).

9) H. Ismail, H. P. S. A. Khalil, Polymer Testing, 20, 33 (2001).

10) M. Kazayawako, J. J. Balatinecz, R. T. Woodhams, J. Applied Polymer Sci, 66, 1163 (1997).

11) J.Simonsen, R. Jacobsen, R. Rowell, J. Applied Polymer Sci, 68, 1567 (1998).

12) C. Xiaoya, G. Qipeng, M. Yongli, J. Applied Polymer Sci, 69, 1891 (1998)

13) A. K. Bledzki, O. Faruk, M. Huque, Polymer Plastics Technology and Engineering, 41, 435 (2002).

14) A. K. Rana, B. C. Mitra, A.N. Banerjee, J. Applied Polymer Sci, 7, 531 (1999).

15) H. D. Rozman, G. B. Penng, J. Applied Polymer Sci, 70, 2647 (1998).

16) W. Qiu, T. Endo, T. Hirotsu, J. Applied Polymer Sci, 10, 4 (2006).

17) W. Qiu, F. Zhang, T. Endo, T. Hirotsu, Polymer Composites, 26, 3830 (2005).

18) H. Ito, R. Kumari, M. Takatani, T. Okamoto, Polymer Eng. Sci, 48, 168 (2008).

19) H. Ito, H. Hattori, I. Fujiyoshi, R. Kumari, M. Uchiyama, T. Okamoto, M. Takatani, Proceeding of the $2^{\text {nd }}$ International Cellulose Conference 2007, 66 (2007).

20) H. Ito, H. Hattori, T. Okamoto, M. Takatani, J. Wood Chemical Technology, in press (2009).

21）伊藤弘和, 服部英広, 岡本忠, 高谷政広, 材料, 58, 292 (2009),

22）特許第 3892019 号.

23）伊藤弘和，服部英広，岡本忠，高谷政広，木材工業， 64,268 (2009).

24) H. Ito, H. Hattori, T. Okamoto, M. Takatani, J. wood chemical Technology, in press (2009). 